\title{
IMPLANT-RETAINED OVERDENTURE AND O-RING ATTACHMENTS - CASE REPORT
}

\section{OVERDENTURE RETIDA POR IMPLANTES E ENCAIXES DO TIPO O'RING: A CASE REPORT}

\begin{abstract}
Andressa BULEGON ${ }^{1}$; Isadora RINALDI ${ }^{2}$; Daniela Cristina MIYAGAKI ${ }^{3}$; Maria Salete Sandini LINDEN ${ }^{4}$; João Paulo de CARLI ${ }^{5}$

1. Undergraduate student at the School of Dentistry of the University of Passo Fundo, RS, Brazil; 2. Postgraduate student at the School of Dentistry of the University of Passo Fundo, RS, Brazil; 3. Professor at the School of Dentistry of the University of Passo Fundo, RS, Brazil. PhD in Endodontics by the Campinas State University, Piracicaba, SP, Brazil; 4. Professor at the School of Dentistry of the University of Passo Fundo, RS, Brazil. PhD in Implantology by Center for Dental Studies São Leopoldo Mandic, Campinas, SP, Brazil. 5. Professor at the School of Dentistry of the University of Passo Fundo, RS, Brazil. PhD in Stomatology by the Pontifical Catholic University, Curitiba, PR, Brazil. joaodecarli@upf.br.
\end{abstract}

\begin{abstract}
The increase in life expectancy occurred along an increase in the demand of edentulous patients for a type of rehabilitation that provides higher masticatory efficiency. Thus, implant overdentures using the ball/o-ring and bar-clip attachment systems represent a muco-supported and implant-retained prosthetic type that allows greater security, stability, and aesthetics, besides presenting a lower cost and easier hygiene. The present study aims to report a clinical case of overdenture with the o-ring retention system. In this case, the patient complained of difficulties during mastication due to instability of the mandibular complete denture, sensitivity from the superficialization of the mental foramina, dissatisfaction with aesthetics, and successive dislocations of the mandibular condyle. After clinical and radiographic evaluation, the treatment proposed was the installation of two osseointegrated implants between the mental foramina and the o-ring attachment overdenture. This prosthetic rehabilitation presents a successful clinical follow-up of 24 months, confirming the effectiveness of the treatment applied. The patient was satisfied because the implant-retained prosthesis provided benefits related to aesthetics, comfort, phonation, and mastication. It is noted that the rehabilitation performed has solved the patient's initial complaints. After the clinical case and literature review, it is concluded that overdentures using the o-ring retention system are viable alternatives and provide adequate function and aesthetics, presenting integration with the stomatognathic system.
\end{abstract}

KEYWORDS: Dental prosthesis. Complete denture. Dental implants. Condylar dislocation. Superficialisation of the mental foramen.

\section{INTRODUCTION}

Over the last decades, implant-supported prostheses have improved the quality of life of completely edentulous patients (CHUN et al., 2005), due to the comfort provided, as well as better aesthetics and masticatory function (NOGUEIRA et al., 2018).

Overdentures have become significantly popular as an alternative treatment to conventional complete dentures. An excellent method for increasing the retention and stability of such dentures is using the o-ring attachment system, which has several advantages, including ease of use, hygiene, and maintenance, and low cost. Disadvantages include attachment wear with gradual retention loss and the need for periodic replacement (MACHADO et al., 2011).

Early reports and techniques tended to direct the prosthetic treatment to the availability of remaining teeth and root shapes that could support and retain a prosthesis. In the mandibular arch, canines and premolars were reported as the teeth most resistant and indicated to receive intraradicular o-rings (MORROW et al., 1969).

The treatment of edentulous jaws with twoimplant-retained overdenture is well accepted, with successful long-term results for prostheses and implants (NAERT et al., 2004). The o-ring attachment system is considered rather resilient for overdentures (BARÃO et al., 2013).

In the light of current knowledge, it is noted that besides replacing lost teeth in an edentulous dental arch and providing retention and stability to the prosthetic restoration, an implant-retained overdenture allows relieving the pressure on superficialized mental foramina (HYDE et al., 2010), restoring a stable occlusal pattern, and returning the vertical dimension of occlusion, which prevents occasional dislocations of the mandibular condyle (LING et al., 2011). 
For the scientific community, cases of implant-retained overdenture highlight the importance of both restorative and surgical considerations when planning the rehabilitation of the mandible with dental implants. For Patel and Walmsley (2014), restoring the edentulous mandible with a removable prosthesis can be a challenging prospect for dentists and patients during and after treatment. Poor retention and support are the major problems reported with a mandibular complete denture and they may be improved significantly with the use of implants and retentive attachments. Using implants requires careful planning from both surgical and restorative aspects to ensure that the intended treatment objective and outcome are achieved.

This study aimed to report a clinical case of lower prosthetic rehabilitation with overdenture retained by an o-ring system in an edentulous patient with bilateral superficialization of the mental nerve, reporting exacerbated sensitivity and discomfort in using the conventional complete denture, as well as consecutive dislocations of the mandibular condyle.

\section{Case Report}

A 60-year-old female patient wearing complete upper and lower conventional prosthesis sought the School of Dentistry of the University of Passo Fundo (UPF) - RS, Brazil, for oral rehabilitation through the installation of osseointegrated implants. She complained of difficulties during mastication, due to the instability of the mandibular complete denture, and pain "in shock" in the region of lower premolars when using the old prosthesis. In addition, the patient reported multiple episodes of "displacement of the mandible in the left side" when speaking or yawning, which was understood as the occurrence of dislocations of the mandibular condyle.

Panoramic X-ray (Figure 1) and intraoral physical examinations revealed a rather reabsorbed lower alveolar ridge, which may be the reason for the lack of stability of the prosthesis. The panoramic radiograph also showed an evident superficialization of the mental foramen, bilaterally. In view of the above, the treatment proposed was the installation of two osseointegrated implants in the interforaminal region and overdenture with o-ring attachments.

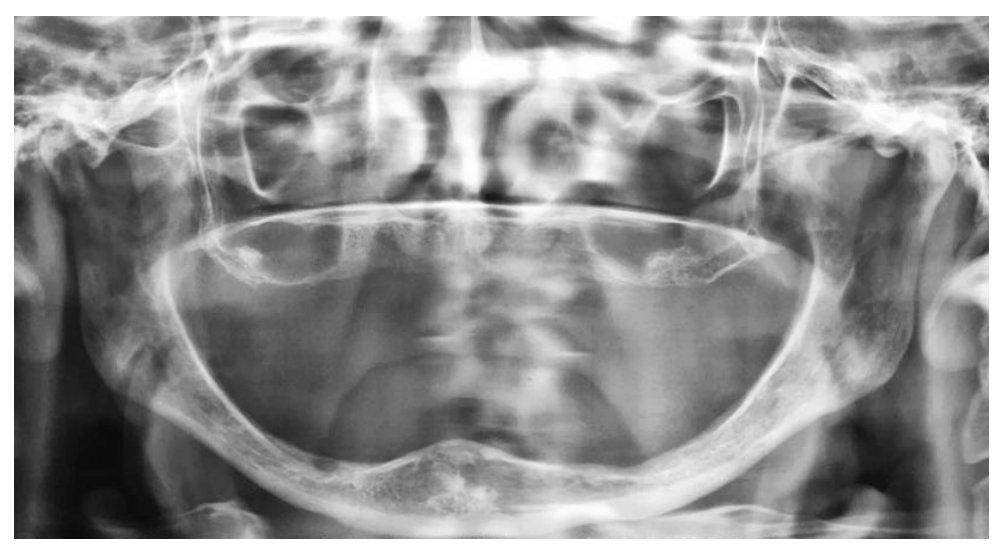

Figure 1. Initial panoramic radiograph

A surgical guide was produced with colorless self-curing acrylic resin from the duplication of the mandibular complete denture that the patient already used. In this guide, holes were made in the canine region to conduct the desired position for the implants during surgery (Figure 2). The implants installed have dimensions of $3.75 \times 10$ $\mathrm{mm}$ in the region of element 43 and $3.75 \times 11.5 \mathrm{~mm}$ in the region of element 33 (Master Double ${ }^{\mathrm{TM}}$, Connecting Systems of Prosthesis, Arujá, São Paulo, Brazil). After implant installation, the old prosthesis used by the patient was repacked with soft resin (Dentusoft ${ }^{\mathrm{TM}}$, Industria Argentina, Buenos Aires, Argentina) and changed periodically during osseointegration.

Four months after the installation of implants, a new panoramic radiograph was performed (Figure 3), in which a uniform radiopacity was observed around the two implants installed, indicating satisfactory osseointegration. Then, the second surgical time was performed, with implants being accessed again for removing the cover screw and installing the healing agents. 


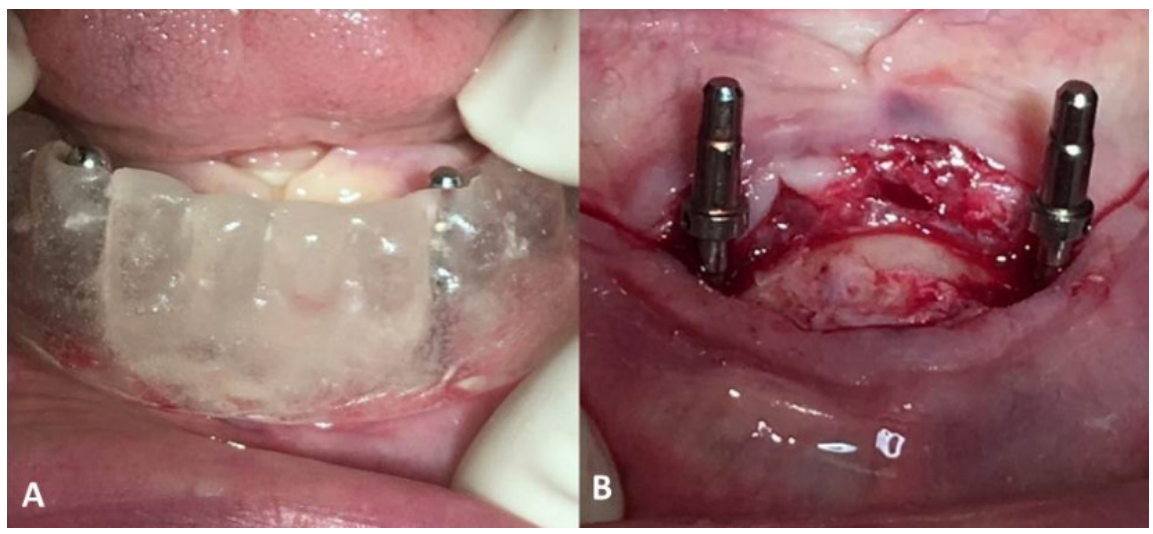

Figure 2. Surgical guide placed in the mouth (A) and position indicators of the implants showing the parallelism of bone perforations (B)

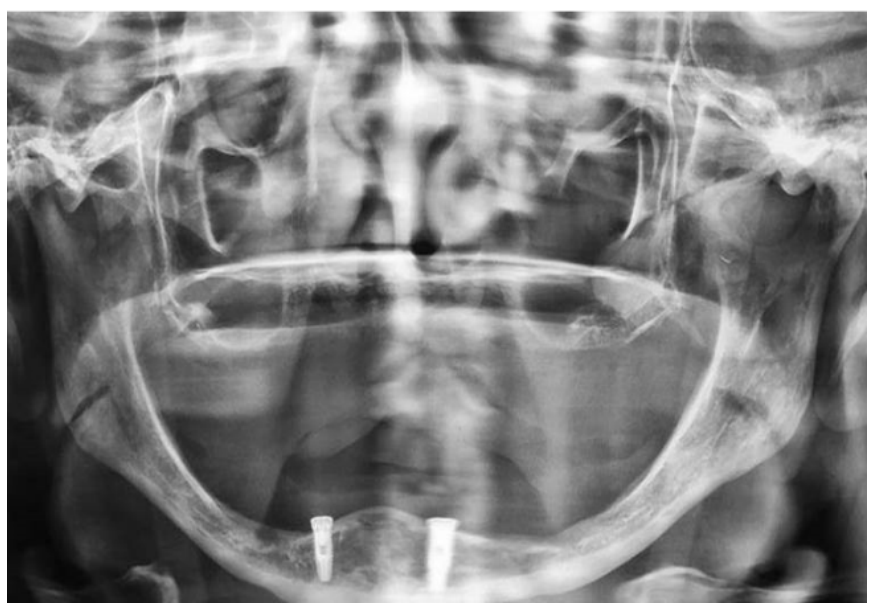

Figure 3. Panoramic radiograph obtained four months after implant installation

The study model of the lower arch was produced with condensation silicone (Zetaplus ${ }^{\mathrm{TM}}$, Labordental Ltda, São Paulo, São Paulo, Brazil), in which retentions and corrective casting were performed with irreversible hydrocolloid (Jeltrate ${ }^{\mathrm{TM}}$, Dentsply Indústria e Comércio Ltda., Petrópolis, Rio de Janeiro, Brazil) in perforated stock trays. The superior prosthesis was duplicated to obtain the antagonist model, considering the patient would use it. After producing the plaster casts, a smaller individual tray was made in a colorless self-curing acrylic resin (Clássico $^{\mathrm{TM}}$, Artigos Odontológicos Clássico Ltda., Campo Limpo Paulista, São Paulo, Brazil) for later peripheral sealing using Godiva in stick form (Exata ${ }^{\mathrm{TM}}$, DFL Indústria e Comércio $\mathrm{S}$. A., Rio de Janeiro, Rio de Janeiro, Brasil), and functional casting using Polyether (Impregum ${ }^{\mathrm{TM}}$, 3M Dental Products, Sumaré, São Paulo, Brazil) (Figure 4).

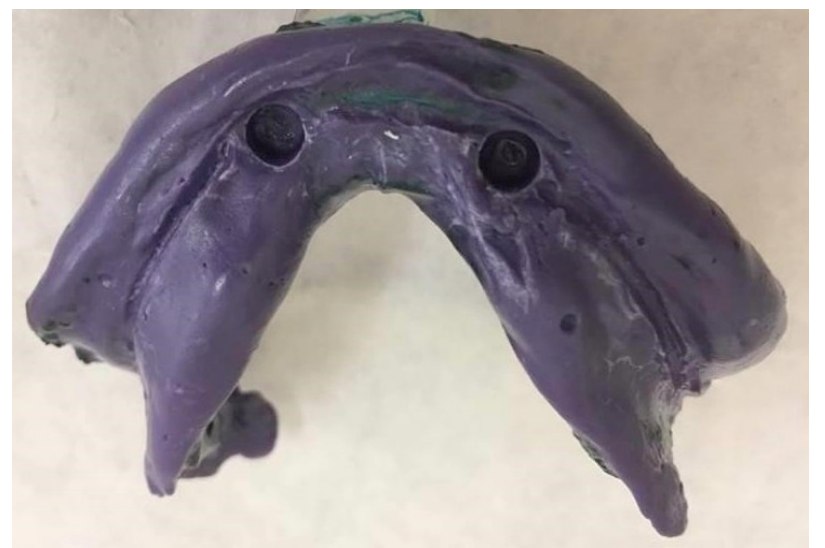

Figure 4. Model obtained from functional casting with polyether 
The gypsum model was produced and a lower test base was made with wax and acrylic resin surfaces, and it was later adjusted in the patient to provide an adequate maxillomandibular relationship (Figure 5). Therefore, the Willis metric method (Figure 6) was used to obtain the vertical dimension, perform the midline marking, and for the assembly in the semi-adjustable articulator. Then, the work was sent to a dental prosthesis laboratory, where artificial teeth (Trilux ${ }^{\mathrm{TM}}$, VIPI Industria, Comércio, Export e Importação de Produtos Odontológicos
Ltda., Pirassununga, São Paulo, Brazil) of shade 4A were assembled. Next, an aesthetic and functional test of the prosthesis was performed and after polymerization, the o-ring abutments were installed on the implants (32N of torque) and the capsules were captured at the base of the complete denture (Figure 7). This prosthetic rehabilitation presents a successful clinical follow-up of 24 months, confirming the efficacy of the treatment applied (Figures 8 and 9).

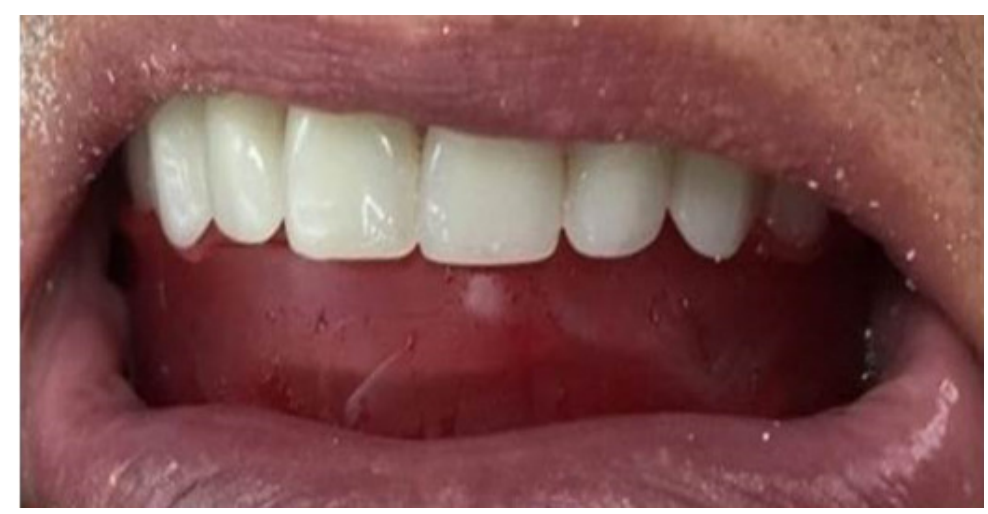

Figure 5. Establishment of the maxillomandibular relationship with a lower test base

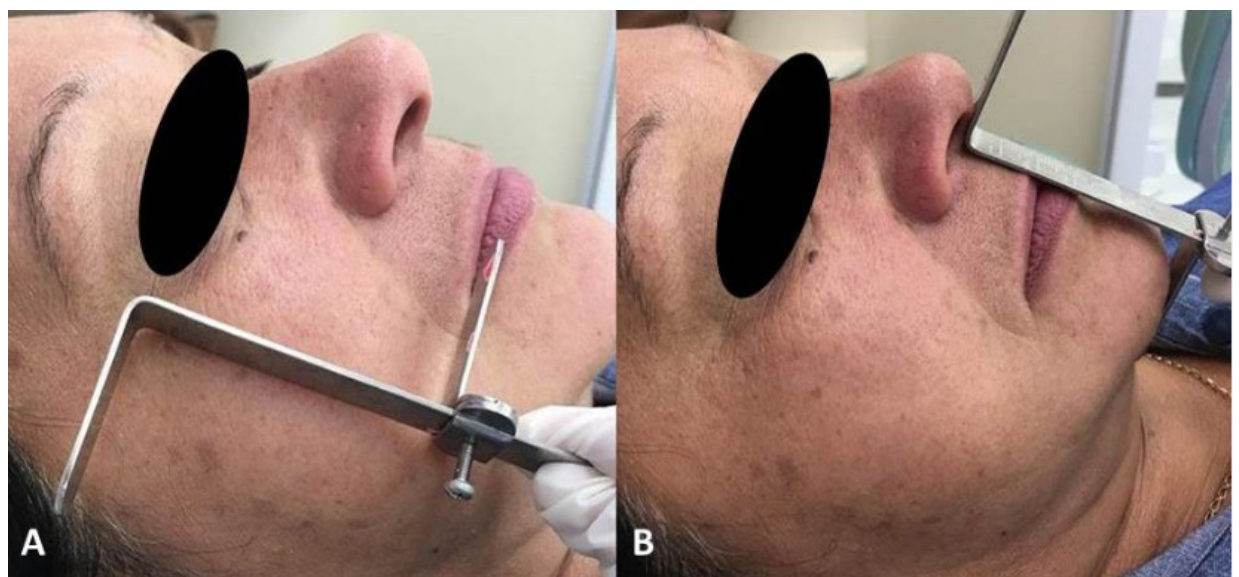

Figure 6. Determination of the vertical dimension of occlusion by the metric method (A and B)

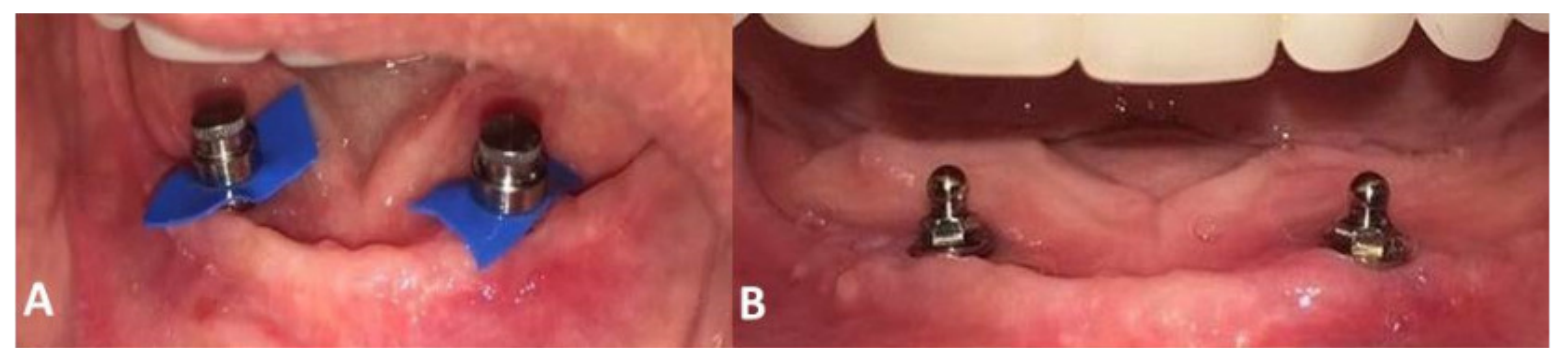

Figure 7. Capsules positioned on the ball abutments (A) and abutments after capsule capture (B) 


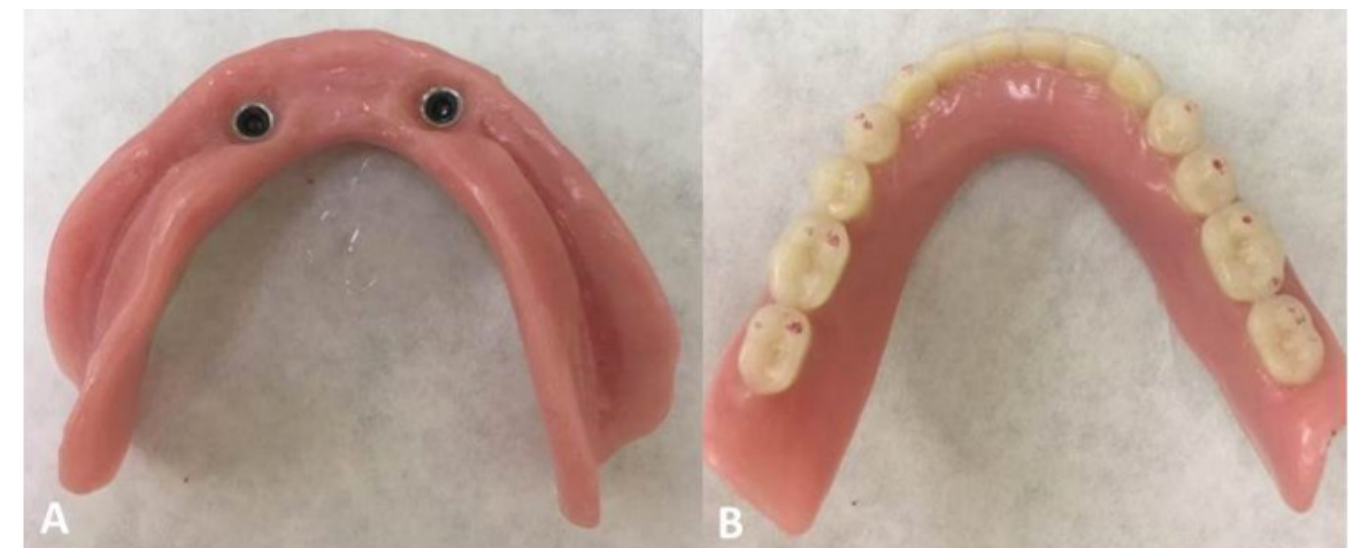

Figure 8. Internal part of the prosthesis with the capsules captured (A) and contact points obtained during the final occlusal adjustment of the prosthesis (B)

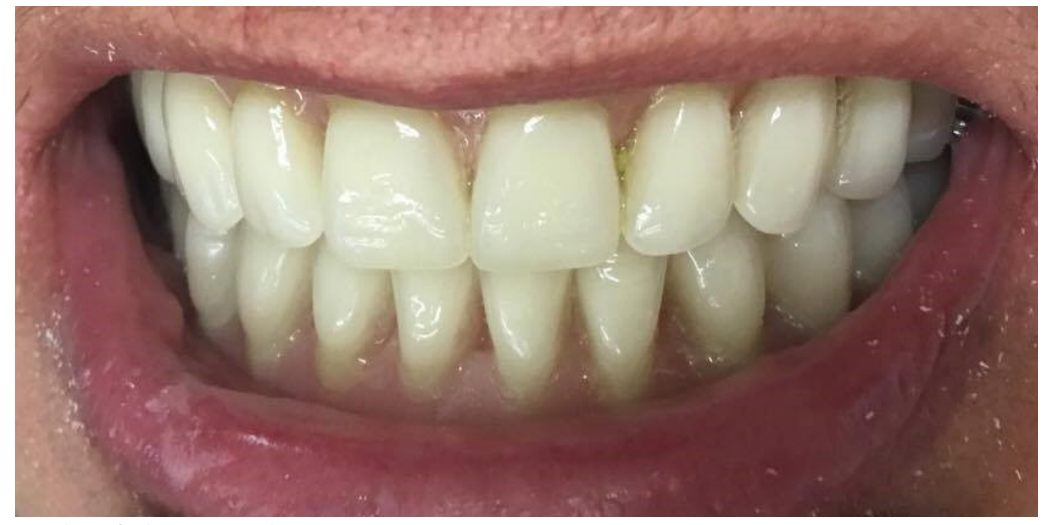

Figure 9. Final aesthetic result of the overdenture

\section{DISCUSSION}

The mandibular overdenture system supported by two implants consists of the installation of two implants in the region between the mental foramina with a complete denture supported on them. This system has become widely used for the rehabilitation of edentulous patients and it is recommended as a good treatment choice because of its clinical efficacy in improving masticatory performance and patient satisfaction (THOMASON et al., 2012).

Tokuhisa et al. (2003) state that the criteria used to select an optimum retention system for the denture should promote good retentivity, providing stability to the prosthesis so there is no major loss of retention capacity over time. This system should also be easy to maintain and inexpensive, as well as present low height so that it may be used in reduced intermaxillary spaces, thus favoring aesthetics. It should also have biomechanical capacity for the distribution of functional loads.

The prognosis of an overdenture depends on two important factors: retention and stress distribution. The success of implanted overdentures depends primarily on the prosthetic retention capacity to maintain long-term functionality (RUTKUNAS et al., 2011). The choice of the prosthetic component depends on the retention required, morphology, anatomy, mucosa, oral function, and patient acceptance (EVTIMOVSKA et al., 2009). In the case hereby reported, considering that a satisfactory parallelism and positioning of implants was obtained in the arch and that the patient was already used to the mandibular complete denture, the ball o-ring system was chosen for retaining the future overdenture.

The ball system is composed of male/female fittings, with the male component normally attached to the abutment and in the form of a narrower neck projection to which the rubber ring (o'ring) of the female component fits. The female component usually has a rubber ring surrounded by a metal capsule, which may have different dimensions and shapes (MERICKE-STERN, 1997). The ball system transfers less stress to the implant and produces less force-momentum than the bar/clip system, suggesting that its use may benefit implant-retained overdentures, despite requiring more frequent maintenance. This system aims to reduce the transmission of stress to the peri-implant bone tissue 
and to minimize prosthesis movement (TOKUHISA et al., 2003; FAJARDO et al., 2014).

The dimensions, the number of implants used, and especially their disposition in the alveolar ridge of the patient should be considered when selecting the type of overdenture retention system. If the implants appear to be divergent, their splinting is recommended, as well as using the bar/clip system or associating the bar with another system, if the patient's intermaxillary space allows. For the ball retention system to be used in non-splinted implants, there must be parallelism with no divergence greater than $5^{\circ}$ between implants (MANJU; SREELAL, 2013).

Ideally, the implants should be parallel to each other and to the insertion path of the prosthesis perpendicular to the occlusal plane, at a similar distance from the midline and at the same height. The absence of these conditions results in increased wear of the prosthetic component, with the friction between the base and the ball abutment resulting in decreased retention values (MACHADO et al., 2011). In the case reported, two implants were placed between the foramina in an attempt to support the prosthesis and decrease the sensitivity the patient felt with the conventional prosthesis. Figure 2 shows the parallelism of the implants installed in the present case, providing a more favorable prognosis.

The height and shape of the ridge should also be observed for the correct selection of the overdenture retention system. In a mandibular overdenture, a more resilient retention system is desired to reduce the effect of the power arm formed by the distal extension of the prosthesis, due to the placement of implants in the anterior mandibular region. A thin triangular arch does not allow the use of a bar with adequate extension, so that it is well positioned over the ridge to allow the clip having sufficient retentivity (BARÃO et al., 2013; NOGUEIRA et al., 2018). In the case of the present study, although the arch was not triangular, the use of the o'ring system was chosen, as the cost of rehabilitation was also considered

Patient age and motor coordination are related to the hygiene of the prosthetic device. It should be considered that older patients present a physiological loss of motor coordination, which suggests the use of isolated implants so that cleaning may be performed more easily by the patient (WATSON et al., 2001; NOGUEIRA et al., 2018).

Moreover, considering the advantages of retention of o-ring components, especially hygiene, cost-effectiveness, and ease of use, the selection of this system in geriatric patients is justified
(WICHMANN \& KUNTZE, 1999). This information supports the clinical decision made in the planning of the present study, whereas the patient of the case was 60 years old at the time of prosthesis production.

When planning this clinical case, attention was given to the superficialization of the mental foramen, which caused considerable discomfort to the patient (HYDE et al., 2010). The effectiveness of the treatment applied in reducing such discomfort was confirmed by the patient with the report of painful symptomatology resolution from prosthesis installation.

It should also be mentioned that after the installation of the overdenture, the patient reported that the episodes of dislocation of the left mandibular condyle had ceased, considering such episodes would constantly upset her and directly affect her quality of life. This finding is in line with an earlier study that reports a direct relationship between adequate oral rehabilitation and condylar dislocations in completely edentulous individuals (LING et al., 2011).

Usually, the combination of prosthetic component materials in overdentures includes metal-metal or metal-plastic/nylon/rubber juxtaposition. The contact between these components may show differences in surface wear and, therefore, resistance to repetitive removal and insertion (SHASTRY et al., 2016). In addition, a change in the retention capacity of fixation systems is expected when the overdenture is subjected to a period of use in the oral cavity under the influence of inherently present fluids, foods and liquids ingested during mastication, and insertion and removal of the prosthesis. Micro and macro movements between the retention surface and the prosthetic components will lead to wear and reduction of retention forces over time (SADOWSKY, 2001).

In the present case, there was a metal-rubber juxtaposition, which is typical of the o-ring system, favoring the absorption of masticatory loads and avoiding an early wear of the prosthetic structures, considering the rubber rings are replaceable. Additionally, the case had 24 months of clinical follow-up and it was found that changing the rubber rings every semester was sufficient for the patient.

Considering that implant failure may result from overloading, the practical goal for the clinician is to avoid excessive stress by properly planning the prosthesis. It is suggested that the o-ring components may provide an adequate system for reducing implant stress and promoting prosthesis stability (MANJU; SREELAL, 2013). It may be 
noted in this study that the prosthesis was planned correctly, as the patient had no complains of sensitivity, showing adequate retention and stability of the prosthesis in the immediate and mediate postoperative periods.

In addition to the need for periodic maintenance of overdentures (exchange of retention elements, implant control radiographs, and professional hygiene), the patient should also be advised on the correct daily hygiene of the prosthesis and oral cavity, as well as on the importance of such hygiene to prevent potential failures associated with peri-implant problems. In this sense, Manju and Sreelal (2013) affirm that the daily maintenance of overdentures retained by the o'ring system is easier than that of overdentures retained by the bar-clip system.

\section{CONCLUSION}

It was observed that the rehabilitation performed responded to the patient's initial complaints, mainly regarding instability of the complete lower conventional prosthesis, symptomatology from the superficialization of the mental foramen, and episodes of dislocation of the mandibular condyle. After the clinical case and literature review, it is concluded that overdentures using the o-ring retention system are viable alternatives and provide adequate function and aesthetics, presenting integration with the stomatognathic system.

RESUMO: Com o aumento da expectativa de vida, houve também o aumento da procura dos pacientes edêntulos por uma forma reabilitadora que lhes proporcione maior eficiência mastigatória. Sendo assim, as sobredentaduras sobre implantes utilizando sistemas de encaixe bola/o'ring e barra-clip representam modalidade protética mucossuportada e implantorretida que possibilita maior segurança, estabilidade e estética, além de apresentarem menor custo e facilidade para higienização. O presente trabalho tem por objetivo relatar um caso clínico de overdenture que utiliza o sistema de retenção o'ring. Neste caso, a paciente queixava-se de dificuldades durante a mastigação devido à instabilidade da prótese total inferior, sensibilidade pela superficialização dos forames mentuais, insatisfação com a estética, além de sucessivas luxações do côndilo mandibular. Após avaliação clínica e radiográfica, o tratamento proposto foi a instalação de dois implantes osseointegráveis entre os forames mentuais e overdenture com encaixes do tipo o'ring. A reabilitação protética em questão apresenta um acompanhamento clínico bem sucedido de 24 meses, comprovando a eficácia do tratamento instituído. A paciente demonstrou estar satisfeita, pois a prótese implanto-retida possibilitou benefícios relacionados à estética, conforto, fonação e mastigação. Nota-se que a reabilitação realizada atendeu às queixas iniciais da paciente. Após a realização do caso clínico e revisão de literatura, conclui-se que overdentures que utilizam o sistema de retenção o'ring são alternativas viáveis e que promovem função e estética adequadas, integrando-se ao sistema estomatognático.

PALAVRAS-CHAVE: Prótese dentária. Prótese total. Implantes dentários. Luxação condilar. Superficialização do forame mentual.

\section{REFERENCES}

BARÃO, V. A.; DELBEN, J. A.; LIMA, J.; CABRAL, T.; ASSUNÇÃO, W. G. Comparison of different designs of implant-retained overdentures and fixed full-arch implant-supported prosthesis on stress distribution in edentulous mandible--a computed tomography-based three-dimensional finite element analysis. J. Biomech., v. 46, n. 7, p. 1312-1320, 2013. https://doi.org/10.1016/j.jbiomech.2013.02.008

CHUN, H. J.; PARK, D. N.; HAN, C. H.; HEO, S. J.; HEO, M. S.; KOAK, J. Y. Stress distributions in maxillary bone surrounding overdenture implants with different overdenture attachments. J. Oral Rehabil., v. 32, n. 3, p. 193-205, 2005. https://doi.org/10.1111/j.1365-2842.2004.01407.x

EVTIMOVSKA, E.; MASRI, R.; DRISCOLL, C. F.; ROMBERG, E. The change in retentive values of locator attachments and hader clips over time. J. Prosthodont., v. 18, n. 6, p. 479-483, 2009.

https://doi.org/10.1111/j.1532-849X.2009.00474.x 
FAJARDO, R. S.; ZINGARO, R. L.; MONTI, L. M. System-retained O'ring and bar-clip overdenture designs. Arch. Health Invest., v. 3, n. 1, p. 77-86, 2014.

http://www.archhealthinvestigation.com.br/ArcHI/article/viewFile/664/859

HYDE, T. P.; CRADDOCK, H. L.; BLANCE, A.; BRUNTON, P. A. A cross-over Randomised Controlled Trial of selective pressure impressions for lower complete dentures. J. Dent., v. 38, n. 11, p. 853-8, 2010. https://doi.org/10.1016/j.jdent.2010.07.003

LING, Y. H.; SHI, H. M.; ZHAO, J. Preliminary analysis of the bilateral disc-condyle relationship of TMJ before and after prosthetic rehabilitation in edentulous patients. Shanghai Kou Qiang Yi Xue, v. 20, n. 5, p. 522-526, 2011.

MACHADO, A. C.; CARDOSO, L.; BRANDT, W. C.; HENRIQUES, G. E.; DE ARRUDA NÓBILO, M. A. Photoelastic analysis of the distribution of stress in different systems of overdentures on osseous-integrated implants. J. Craniofac. Surg., v. 22, n. 6, p. 2332-2336, 2011. https://doi.org/10.1097/SCS.0b013e318232a791

MANJU, V.; SREELAL, T. Mandibular implant-supported overdenture: an in vitro comparison of ball, bar, and magnetic attachments. J. Oral Implantology, v. 39, n. 3, p. 302-307, 2013. https://doi.org/10.1563/AAID-JOID-11-00050

MERICKE-STERN, R. Force distribution on implants supporting overdentures: the effect of distal bar extensions. A 3-D study. Clin. Oral Impl. Res., v. 8, n. 2, p. 142-151, 1997. https://doi.org/10.1034/j.16000501.1997.080209.x

MORROW, R. M.; FELDMANN, E. E.; RUDD, K. D.; TROVILLION, H. M. Tooth-supported complete dentures: an approach to preventive prosthodontics. J. Prosth. Dentistry, v. 21, n. 5, p. 513-522, 1969. https://doi.org/10.1016/0022-3913(69)90073-0

NAERT, I.; ALSAADI, G.; QUIRYNEN, M. Prosthetic aspects and patient satisfaction with two-implantretained mandibular overdentures: a 10-year randomized clinical study. Int. J. Prosthodontics, v. 17, n. 4, p. 401-410, 2004. https://doi.org/10.1016/j.prosdent.2004.09.021

NOGUEIRA, T. E.; AGUIAR, F. M. O.; DE BARCELOS, B. A.; LELES, C. R. A 2-year prospective study of single-implant mandibular overdentures: Patient-reported outcomes and prosthodontic events. Clin. Oral Implants Res. 2018; Apr 16. https://doi.org/10.1111/clr.13151

PATEL, U.; WALMSLEY, D. Implant-supported mandibular denture: planning to delivery-a case report. Dent Update, v. 41, n. 2, p. 137-140, 2014. https://doi.org/10.12968/denu.2014.41.2.137

RUTKUNAS, V.; MIZUTANI, H.; TAKAHASHI, H.; IWASAKI, N. Wear simulation effects on overdenture study attachments. Dent. Mater. J., v. 30, n. 6, p. 845-853, 2011. https://doi.org/10.4012/dmj.2011-057

SADOWSKY, S. J. Mandibular implant-retained overdentures: a literature review. J. Prosthet. Dent., v. 86, n. 5, p. 468-473, 2001. https://doi.org/10.1067/mpr.2001.119921

SHASTRY, T.; ANUPAMA, N. M.; SHETTY, S; NALINAKSHAMMA, M. An in vitro comparative study to evaluate the retention of different attachment systems used in implant-retained overdentures. J. Indian Prosthodont. Soc., v. 16, n. 2, p. 159-166, 2016. https://doi.org/10.4103/0972-4052.176520

THOMASON, J. M.; KELLY, S. A.; BENDKOWSKI, A.; ELLIS, J. S. Two implant retained overdentures-A review of the literature supporting the McGill and York consensus statements. J. Dent., v. 40, n. 1, p. 22-34, 2012. https://doi.org/10.1016/j.jdent.2011.08.017 
TOKUHISA, M.; MATSUSHITA, Y.; KOYANO, K. In vitro study of a mandibular implant overdenture retained with ball, magnet, or bar attachments: Comparison of load transfer and denture stability. Int. J. Prosthodont., v. 16, n. 2, p. 128-134, 2003. https://doi.org/10.1016/S0022-3913(03)00339-1

WATSON, C. J.; TINSLEY, D.; SHARMA, S. Implant complication and failures: the complete overdenture. Dent. Update, v. 28, p. 234-240, 2001. https://doi.org/10.12968/denu.2001.28.5.234

WICHMANN, M. G.; KUNTZE, W. Wear behavior of precision attachments. Int. J. Prosthodont., v. 12, n. 5 , p. 409-414, 1999. 